Jurnal Health Sains: p-ISSN: 2723-4339 e-ISSN: 2548-1398

Vol. 2, No. 8, Agustus 2021

\title{
PERANCANGAN SISTEM INFORMASI RETENSI REKAM MEDIS PASIEN RAWAT INAP MENGGUNAKAN VISUAL STUDIO 2010 DI RUMAH SAKIT JASA KARTINI TASIKMALAYA
}

\author{
Resa Yusnia, Sali Setiatin, Widya Nadiroh, Candra Mecca Sufyana \\ Rekam Medis dan Informasi Kesehatan, Politeknik Piksi Ganesha, Bandung 1,2, \\ Kepala Rekam Medis, Rumah Sakit Jasa Kartini, Tasikmalaya ${ }^{3}$ \\ Manajemen Informatika, Politeknik Piksi Ganesha, Bandung ${ }^{4}$ Jawa Barat, Indonesia \\ Email: ryusnia@piksi.ac.id, salisetiatin@gmail.com,widyanadiroh@gmail.com, \\ candra86mecca@gmail.com
}

\begin{tabular}{ll}
\hline INFO ARTIKEL & ABSTRAK \\
\hline Diterima & Rumah sakit merupakan tempat menyelenggarakan upaya kesehatan \\
5 Agustus 2021 & yaitu setiap kegiatan untuk memelihara dan meningkatkan kesehatan \\
Direvisi & serta bertujuan untuk mewujudkan derajat kesehatan yang optimal bagi \\
15 Agustus 2021 & masyarakat. Penelitian ini bertujuan untuk merancang sistem informasi \\
Disetujui & retensi rekam medis pasien rawat inap menggunakan microsoft Visual \\
25 Agustus 2021 & Studio 2010 di Rumah Sakit Jasa Kartini Tasikmalaya. Metode \\
\hline Kata Kunci: & penelitian yang digunakan adalah metode kualitatif dengan pendekatan \\
sistem informasi; & deskriptif. Teknik pengumpulan data yaitu dengan cara observasi, \\
rekam medis; & wawancara dan studi pustaka yang terkait dengan pokok permasalahan \\
retensi; DFD & penelitian. Sedangkan untuk metode pengembangan perangkat lunak \\
& menggunakan waterfall. Berdasarkan penelitian yang dilakukan, \\
& ditemukan berbagai masalah diantaranya berkas rekam medis yang telah \\
& diretensi tidak tertata baik pada saat penyimpanannya sehingga tidak \\
& berurutan sesuai nomor rekam medisnya, kurangnya rak penyimpanan \\
& sehingga rekam medis tidak tertata baik dan lambatnya proses retensi. \\
& Oleh karena itu perlu konsep perancangan sistem informasi retensi \\
& rekam medis dalam bentuk aplikasi. Metode perancangan sistem \\
& menggunakan Flowmap, DFD (Data Flow Diagram) dan ERD (Entity \\
& Relation Diagram) serta dimplementasikan dengan bahasa \\
& pemrograman Microsoft Visual Studio 2010 dengan database Microsoft \\
& Access. Pengujian dilakukan dengan menggunakan blackbox dengan \\
& hasil setiap form sukses sesuai prosedur perancangan.
\end{tabular}

\section{ABSTRACT}

The hospital is a place to organize health efforts, namely every activity to maintain and improve health and aims to realize optimal levels of health for the community. This study aims to design an information system for inpatient medical record retention using Microsoft Visual Studio 2010 at the Jasa Kartini Hospital, Tasikmalaya. The research method used is a qualitative method with a descriptive approach. Data collection techniques are using observation, interviews and literature studies related to the subject matter of the research. As for the software development method using the waterfall. Based on the research conducted, various problems were found, including the medical record files that had been retained were not well organized at the time of storage so that they were not sequentially according to the medical 


\begin{tabular}{|c|c|}
\hline & $\begin{array}{l}\text { record number, the lack of storage racks so that the medical records } \\
\text { were not well organized and the retention process was slow. Therefore, } \\
\text { it is necessary to design a medical record retention information system } \\
\text { in the form of an application. The system design method uses Flowmap, }\end{array}$ \\
\hline $\begin{array}{l}\text { Keywords: } \\
\text { information system; } \\
\text { medical record; } \\
\text { retention; DFD }\end{array}$ & $\begin{array}{l}\text { DFD (Data Flow Diagram) and ERD (Entity Relation Diagram) and is } \\
\text { implemented with Microsoft Visual Studio } 2010 \text { programming language } \\
\text { with Microsoft Access database. Testing is done using the black box with } \\
\text { the results of each successful form according to the design procedure. }\end{array}$ \\
\hline
\end{tabular}

\section{Pendahuluan}

Rumah sakit merupakan tempat menyelenggarakan upaya kesehatan yaitu setiap kegiatan untuk memelihara dan meningkatkan kesehatan serta bertujuan untuk mewujudkan derajat kesehatan yang optimal bagi masyarakat (Ade Supriyadi, 2018). Menurut undang-undang Republik Indonesia No 44 Tahun $\backslash 2009$ tentang rumah sakit, rumah sakit mempunyai tugas memberikan pelayanan kesehatan berupa penyelenggarakan pelayanan pengobatan dan pemulihan kesehatan sesuai standar pelayanan rumah sakit, pemeliharaan dan peningkatan kesehatan perorangan melalui pelayanan yang paripurna, penyelenggaraan pendidikan dan pelatihan sumber daya manusia dalam rangka peningkatan kemampuan dalam pemberian pelayanan kesehatan, penyelenggaraan penelitian dan pengembangan teknologi bidang kesehatan dalam rangka peningkatan pelayanan kesehatan dengan memperhatikan etika ilmu pengetahuan bidang kesehatan (Basabih, 2018). Rumah sakit dalam memberikan pelayanan kepada pasien harus memperhatikan mutu dan kualitas. Mutu pelayanan kesehatan suatu rumah sakit dapat dilihat dari peningkatan kualitas pelayanan kepada pasien termasuk kualitas pendokumentasian rekam medis. Rekam medis merupakan berkas yang berisikan catatan dan dokumen tentang identitas pasien, pemeriksaan, pengobatan, tindakan, dan pelayanan lain kepada pasien pada sarana pelayanan kesehatan (Hatta, 2011).

Untuk meningkatkan mutu pelayanan, rumah sakit membutuhkan perekam medis dan informasi kesehatan yang dapat bertanggungjawab dalam pengolahan berkas rekam medis pasien pada rumah sakit. Dimana berkas rekam medis merupakan rangkuman catatan bagi pasien yang telah dirawat disuatu Rumah Sakit. Suatu berkas rekam medis dikatakan baik apabila petugas dapat melaksanakan pencatatan data dengan baik, lengkap, akurat dan tepat waktu (Kusuma \& Sugiarsi, 2010).

Rekam medis sangat berperan penting dalam kelancaran proses pelayanan kesehatan kepada pasien. Menurut Permenkes No.269/MENKES/Per/III/2008 tentang standar profesi perekam medis dan informasi kesehatan, seorang perekam medis harus mampu menetapkan kode penyakit dan tindakan dengan tepat sesuai denganklasifikasi yang diberlakukan di Indonesia (ICD-10) (Syafriani, 2018). Penentuan kode penyebab dasar kematian merupakan salah satu fungsi yang penting dari unit kerja rekam medis yang membutuhkan ketelitian (Pratiwi, 2013). Untuk menentukan kode, petugas harus memperhatikan prosedur atau aturan yang ditetapkan oleh WHO di dalam ICD-10. Berdasarkan hasil observasi, wawancara, dan studi pustaka yang dilakukan oleh penulis penelitian ini bertujuan untuk merancang sistem informasi retensi rekam medis pasien rawat inap menggunakan Microsoft Visual Studio 2010 di Rumah Sakit Jasa Kartini Tasikmalaya. Metode penelitian yang digunakan adalah metode kualitatif dengan pendekatan deskriptif. Sedangkan untuk metode pengembangan perangkat lunak menggunakan waterfall dan 
Perancangan Sistem Informasi Retensi Rekam Medis Pasien Rawat Inap Menggunakan Visual Studio 2010 di Rumah Sakit Jasa Kartini Tasikmalaya

diimplementasikan dengan bahasa pemrograman Microsoft Visual Studio 2010 dengan database Microsoft Access. Pengujian dilakukan dengan menggunakan blackbox dengan hasil setiap form sukses sesuai prosedur perancangan.

Salah satu aspek kehidupan manusia yang tergantung terhadap informasi adalah bidang kesehatan. Pelayanan kesehatan kepada masyarakat dilakukan salah satunya melalui rumah sakit sebagai fasillitas pelayanan kesehatan rawat jalan. Rumah sakit menyelenggarakan pelayanan kesehatan yang bersifat promotif, preventif, kuratif dan rehabilitatif (Khariza, 2015). Hal terpenting dalam rumah sakit adalah sebagai sarana dan prasarana sebagai penunjang yang mengatasi masalah-masalah kesehatan secara memadai dan professional (Rikomah, 2017). Dalam pelayanan kesehatan tidak terlepas dari perkembangan teknologi agar mampu memberikan pelayanan kesehatan masyarakat secara lebih efisien, meningkatkan efektivitas dan produktivitas kerja serta menguatkan fungsi stratejik organisasi kesehatan masyarakat dengan memanfaatkan informasi kesehatan dari berbagai sumber. Dengan demikian seorang praktisi kesehatan masyarakat harus mampu menggunakan informasi kesehatan secara efektif dan mampu mengembangkan, mengelola serta memelihara program teknologi informasi kesehatan masyarakat secara efektif (Taryanto \& Handayani, 2019).

Proses pendokumentasian data berkas rekam medis yang telah di retensi di Rumah Sakit Jasa Kartini masih cara manual, yaitu dengan mengarsipkannya kedalam buku yang disebut buku retensi dan penyimpanan data retensi tidak tertata dengan baik. Hal ini jelas sangat tidak efektif dan efisien apabila diperlukan dikemudian hari, selain itu jika dihubungkan dengan kemajuan teknologi yang ada pada saat ini dihadapkan kondisi dan situasi diatas serta dalam rangka meningkatan mutu pelayanan yang baik, maka Penulis tertarik untuk mengetahui lebih jauh bagaimana kegiatan retensi yang dilakukan dan bagaimana mengembangkan sistem informasi pada kegiatan retensi berkas rekam medis pasien rawat inap di Rumah Sakit Jasa Kartini. Sedangkan aplikasi yang dibangun menggunakan Microsoft Visual Studio 2010.

\section{Metode Penelitian}

Metode penelitian yang digunakan adalah metode kualitatif melalui pendekatan deskriptif. Penelitian kualitatif merupakan "metode yang digunakan untuk meneliti kondisi objektif yang alamiah dimana peneliti adalah sebagai instrumen kunci, teknik penelitian data dilakukan secara gabungan, analisa data bersifat induktif, hasil penelitian lebih menekankan pada makna daripada generalisasi”. (Sugiyono, 2011).

Penelitian dilakukan di Rumah Sakit Jasa Kartini adalah dengan cara teknik pengumpulan hasil data yang diperoleh yaitu:

Observasi, Penulis melakukan penelitian secara langsung dengan melakukan pengamatan terhadap objek penelitian dan menganalisa secara kualitatif pelaksanaan retensi yang berjalan serta sistem yang digunakan.

Wawancara, penulis juga melakukan wawancara demgan petugas rekam medis untuk mendapatkan data yang tidak didapatkan melalui teknik observasi. Teknik ini dilakukan untuk mendapatkan data yang berkaitan dengan masalah yang diteliti melalui penuturan langsung dari petugas rekam medis.

Studi pustaka, Konsep-konsep teori yang relevan dapat diperoleh dari berbagai buku-buku sebagai referensi dan kajian-kajian pustaka yang dapat menjadi landasan penelitian. Selain itu, penulis juga memanfaatkan informasi-informasi yang terdapat pada situs internet.

Pengembangan sistem informasi retensi rekam medis pasien rawat inap menggunakan 
metode perangkat lunak waterfal. Metode Waterfall adalah model yang melakukan pendekatan pada perkembangan perangkat lunak secara sistematik dan sekuensial (Widiyanto, 2018).

Menurut (Pressman et al., 2010), model proses waterfall yang juga dikenal dengan classic life cycle, adalah "model klasik yang bersifat sistematis, berurutan dalam mengembangan perangkat lunak". Model ini melingkupi aktivitas-aktivitas seperti ditunjukkan pada gambar berikut ini:

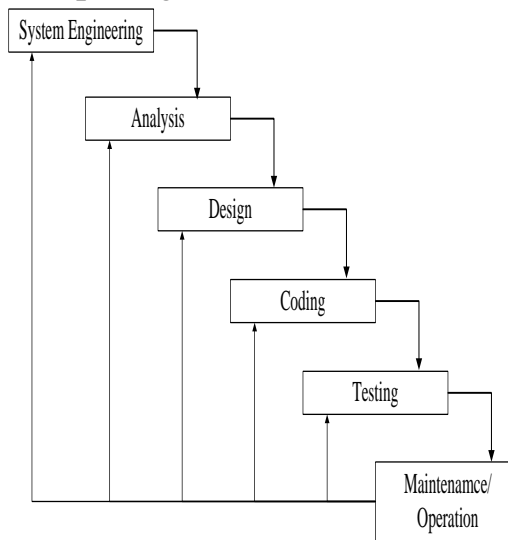

\section{Gambar 1}

\section{Waterfall atau Model Air Terjun Sumber: Pressman (2010)}

Rekayasa Sistem Informasi (System Information Engineering), Merupakan tahap dimana sasaran yang akan diteliti ditinjau terlebih dahulu.

Analisis (Analysis), Merupakan tahapan dimana menganalisis semua kebutuhan yang diperlukan dalam pelaksanaan pengembangan perangkat lunak dan menetapkan informasi domain untuk perangkat lunak, seperti fungsi untuk kerja dan antar muka.

Perancangan, Merupakan tahap perancangan sistem yang akan dibangun seperti arsitektur sistem perangkat lunak dan karakteristik antar muka.

Pengkodean, Merupakan tahap menterjemahkan desain kedalam bahasa pemrograman yang sesuai dengan kebutuhan.
Pengujian, Merupakan tahap
pengujian perangkat lunak yang dikembangkan untuk menganalisa kesalahankesalahan dan menjamin bahwa masukan sesuai dengan hasil yang dibutuhkan.

Maintenance, Pemeliharaan adalah penerapan secara keseluruhan disertai pemeliharaan jika perubahan struktur baik bagi software maupun hardware.

\section{Hasil dan Pembahasan}

\section{A. Hasil Penelitian}

Berdasarkan hasil observasi, wawancara yang telah dilakukan oleh peneliti di Rumah Sakit Jasa Kartini Tasikmalaya pada tanggal 5 April - 5 Juni 2021 sudah melakukan retensi rekam medis dan pelaksanaan tersebut terakhir tahun 2018 dengan jumlah dokumen rekam medis 6692 dokumen yang telah diretensi.

Tahapan pelaksanaan retensi rekam medis pasien rawat inap dipisahkan dari rak aktif ke inaktif berdasarkan tanggal terkahir pasien datang berobat setelah 5 tahun dan rekam medis di ambil dan dipilah dari ruang filing aktif dipindahkan ke ruangan inaktif. Setelah itu ketentuan lama penyimpanan rekam medis inaktif di ruangan sekitar 2 tahun lamanya lalu melakukan pemusnahan.

Pelaksanaan retensi dilakukan setiap 7 tahun sekali sesuai dengan Standar Operasional Prosedur (SOP) yang berlaku di Rumah Sakit Jasa Kartini Tasikmalaya. Hal ini dapat menyebabkan kapasitas penyimpanannya berkurang dan tidak menumpuk di ruangan filing.

Langkah - langkah dalam pemilahan retensi diantaranya:

a. Membuat jadwal retensi (penyusutan) Rekam Medis Rawat Jalan dan Rawat Inap Membuat jadwal retensi (penyusutan) Rekam Medis Rawat Jalan dan Rawat Inap. 
Perancangan Sistem Informasi Retensi Rekam Medis Pasien Rawat Inap Menggunakan Visual Studio 2010 di Rumah Sakit Jasa Kartini Tasikmalaya

b. Melakukan kegiatan retensi setiap bulan untuk memisahkan antara Rekam Medis aktif dengan Rekam Medis inaktif

c. Rekam Medis yang sudah di retensi disimpan terpisah dengan rekam Medis aktif

d. Rekam Medis hasil retensi rusak tak terbaca dapat langsung dimusnahkan sesuai prosedur

e. Melakukan kegiatan penilaian guna Rekam Medis (oleh team pemusnah) yang ditetapkan Kepala Rumah Sakit yang telah 2 (dua) tahun inaktif dengan indikator penilaian

1) Sering Rekam Medis digunakan sebagai penelitian/pendidikan

2) Aspek Admnistrasi, Hukum, Keuangan, IPTEK

3) Pembuktian/sejarah

f. Memisahkan Lembar Rekam Medis yang mempunyai nilai guna dan harus di abadikan yaitu meliputi

1) Ringkasan Masuk dan Keluar

2) Resume Penyakit

3) Lembar Operasi

4) Lembar Persetujuan (informed consent)

5) Identifikasi bayi lahir hidup

6) Lembar kematian

g. Mengumpulkan lembar-rembar rekam medis sisanya termasuk Rekam Medis yang sudah rusak tak terbaca dan disiapkan untuk dimusnahkan

1) Membuat daftar pertelaan nilai guna Rekam Medis

2) Berita acara pemusnahan asli disimpan di Rumah Sakit

3) Melakukan pemusnahan dengan cara dibuat bubur. Bila dilakukan oleh pihak ke tiga, harus disaksikan oleh tim Pemusnah dan dibuat Berita Acara Pemusnahan.

Perancuangan Proses sistem yang berjalannya yaitu:

a) Flowmap disajikan pada gambar 2 .

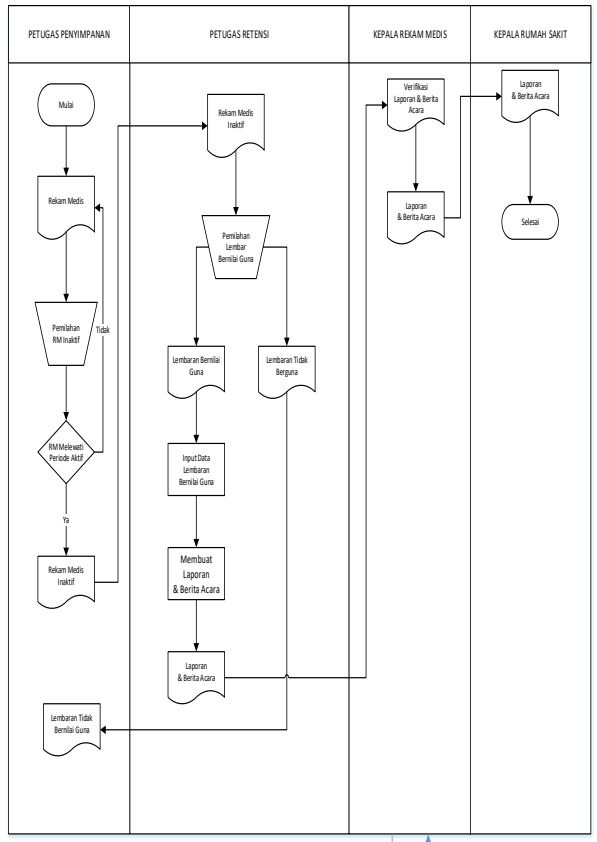

Gambar 2

\section{Flowmap Sistem yang Dirancang}

Perancangan sistem informasi ini diawali dengan menampilkan form login user, yaitu langkah awal untuk mengakses dan melakukan input data rekam medis pasien kedalam sistem yang nantinya akan menghasilkan sebuah data rekam medis aktif, inaktif, dan nonaktif dan menghasilkan keluaran laporan retensi untuk dilaporkan kepada Kepala Rekam Medis dan Direktur Rumah Sakit.

b) Diagram Konteks

Diagram konteks sistem retensi disajikan pada gambar 3 .

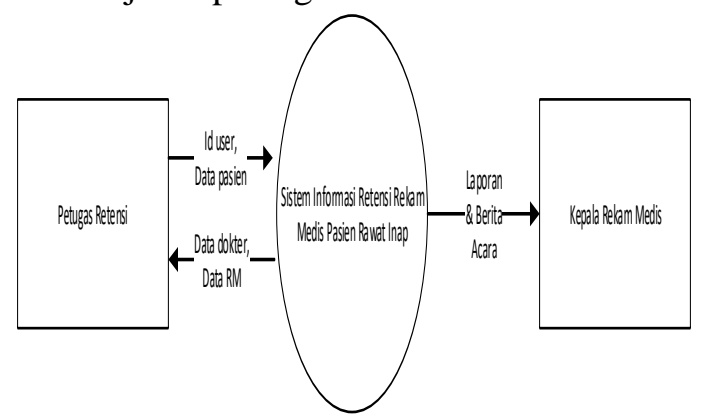

Gambar 3

Diagram Konteks yang Dirancang 
Petugas rekam medis melakukan input data petugas rekam medis, data data pasien, data rekam medis rawat inap, data dokter, dan retensi rekam medis rawat inap ke dalam system informasi retensi rekam medis rawat inap yang nantinya akan menghasilkan sebuah data rekam medis aktif, inaktif, dan nonaktif yang akan di laporkan kepada Direktur Rumah Sakit dan Kepala Rekam Medis.

Data Flow Daigram level 0 disajikan pada gambar 4.

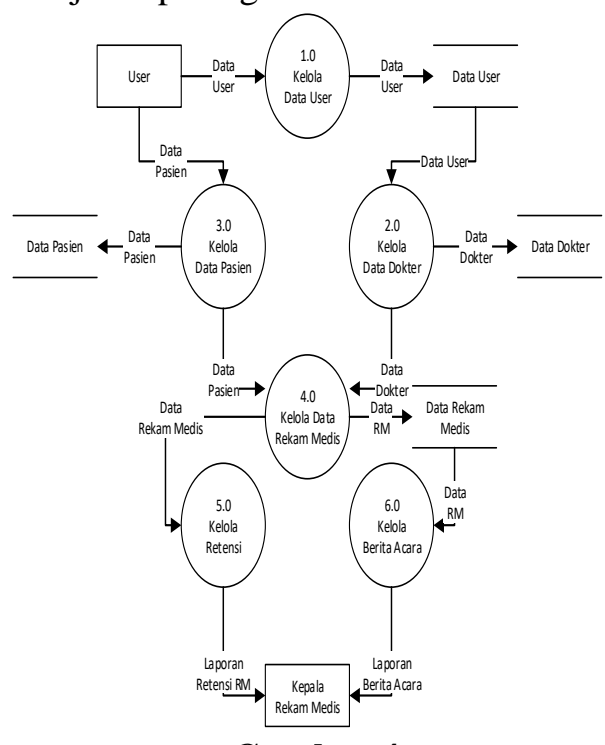

Gambar 4

DFD Level 0 Sistem yang Dirancang

Petugas rekam medis melakukan

Kelola data petugas yang akan tersimpan di data petugas, kelola data pasien yang tersimpan di data sub pasien, kelola data dokter yang tersimpan di data sub dokter kelola data rekam medis yang tersimpan di data sub rekam medis, dan Kelola retensi yang diambil datanya dari data sub rekam medis dan membuatkan laporan retensi untuk dilaporkan kepada Direktur RS dan Kepala Rekam Medis.

Data Flow Diagram Level 1 Proses 1.0 Kelola Data User disajikan pada gambar 5 .

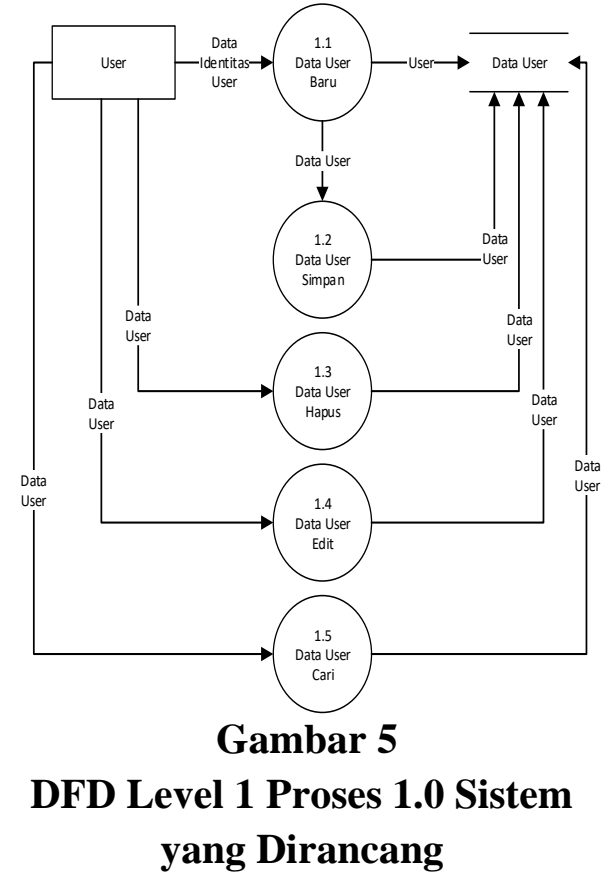

Petugas rekam medis mempunyai akses untuk menambah atau menyimpan, mengedit, menghapus dan mencari data petugas didalam proses penginputan data petugas, dimana dalam proses setiap petugas yang ditambahkan akan otomatis tersimpan di data sub petugas dan memiliki akses yang sama dengan user atau petugas yang lain.

Data Flow Diagram Level 1 Proses 2.0 Kelola Data Dokter disajikan pada gambar 6 . 


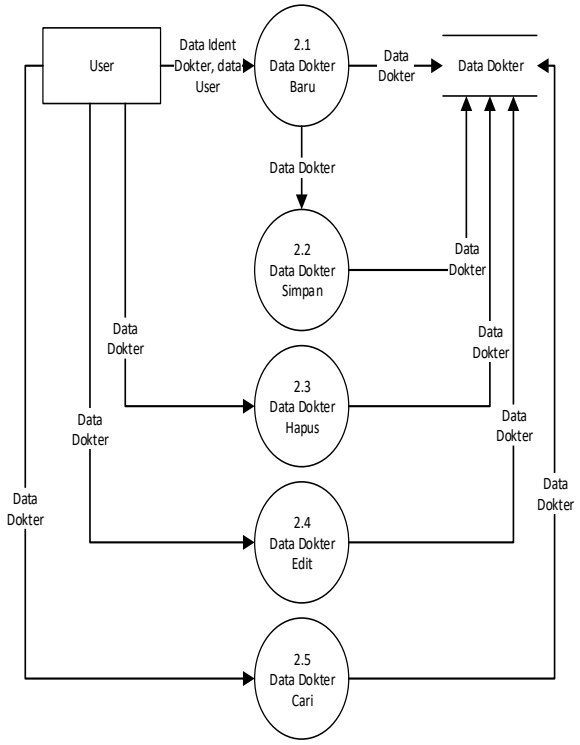

Gambar 6

DFD Level 1 Proses 2.0 Sistem yang Dirancang

Petugas rekam medis mempunyai akses untuk menambah atau menyimpan, mengedit, menghapus dan mencari data pasien didalam proses penginputan data pasien, dimana dalam proses setiap pasien yang ditambahkan akan otomatis tersimpan di data sub pasien.

Data Flow Diagram Level 1 Proses 3.0 Kelola Data Pasien disajikan pada gambar 7 .

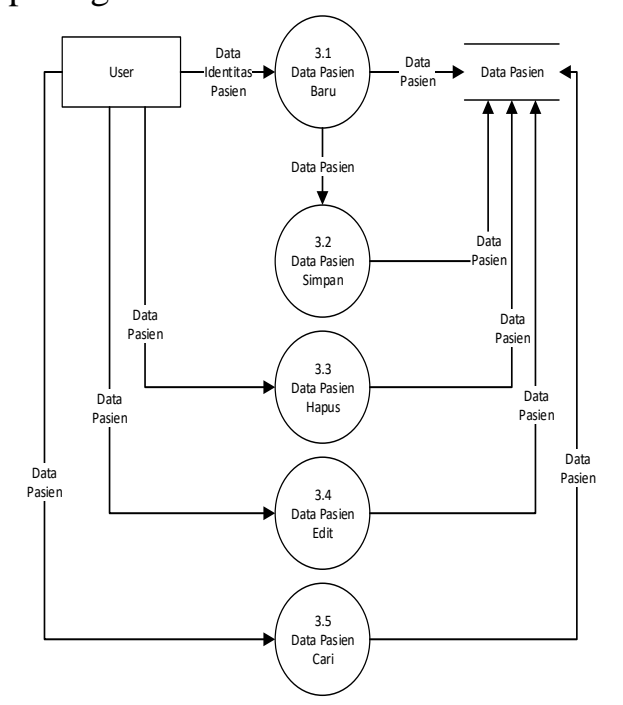

Gambar 7

DFD Level 1 Proses 3.0 Sistem yang Berjalan
Petugas rekam medis mempunyai akses untuk menambah atau menyimpan, mengedit, menghapus dan mencari data dokter didalam proses penginputan data dokter, dimana dalam proses setiap dokter yang ditambahkan akan otomatis tersimpan di data sub dokter.

Data Flow Diagram Level 1 Proses 4.0 Kelola Data Rekam Medis disajikan pada gambar 8 .

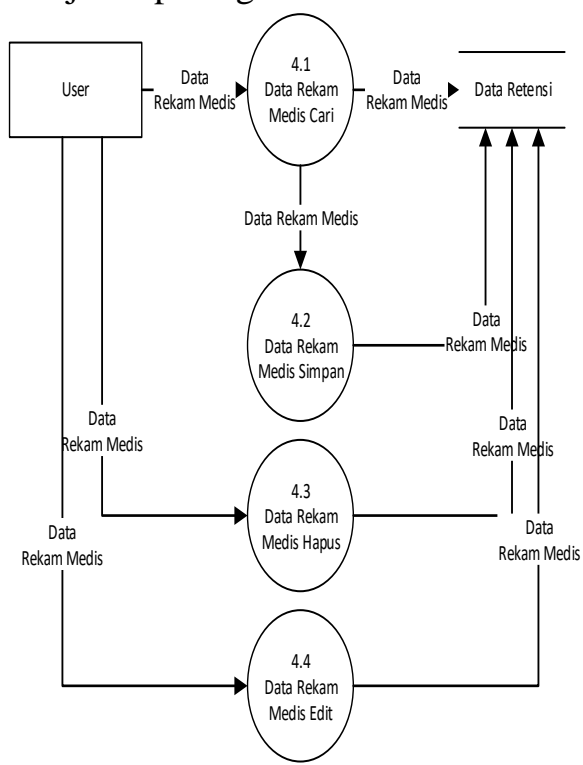

Gambar 8

DFD Level 1 Proses 4.0 Sistem yang Dirancang

Petugas rekam medis mempunyai akses untuk menambah atau menyimpan, mengedit, menghapus dan mencari data rekam medis rawat inap didalam proses penginputan data rekam medis rawat inap, dimana dalam proses setiap data yang ditambahkan akan otomatis tersimpan di data sub rekam medis rawat inap.

Data Flow Diagram Level 1 Proses 5.0 Kelola Data Retensi disajikan pada gambar 9 . 


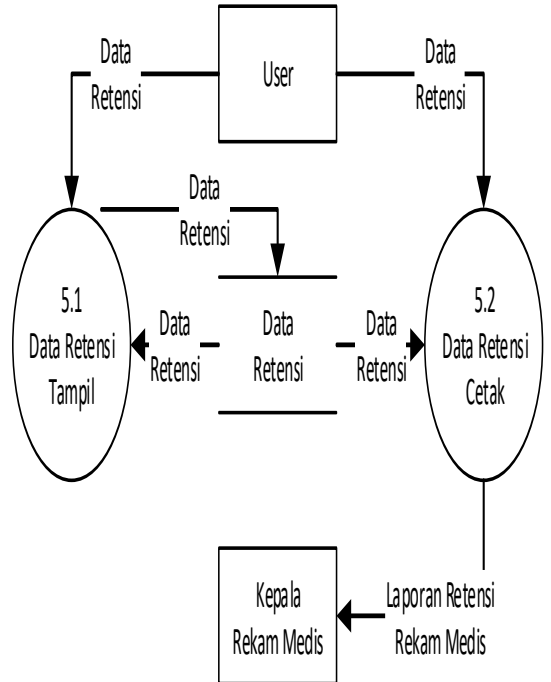

Gambar 9

DFD Level 1 Proses 5.0 Sistem yang Dirancang

Petugas Rekam Medis melakukan pengolahan data retensi yang datanya diambil dari data sub rekam medis rawat inap untuk dipilah menjadi data aktif, inaktif, dan non aktif.

Data Flow Diagram Level 1 Proses 6.0 Kelola Berita Acara disajikan pada gambar 10.

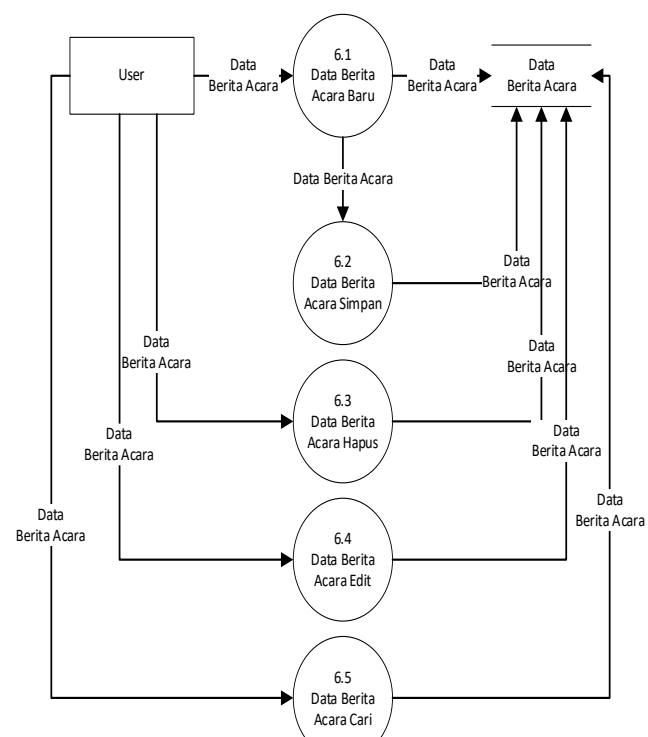

Gambar 10

DFD Level 1 Proses 6.0 Sistem yang

Dirancang
Petugas rekam medis mempunyai akses untuk menambah data berita acara, menyimpan data berita acara, menghapus data berita acara, mengubah data berita acara dan mencari data berita data rekam medis rawat inap didalam proses penginputan data rekam medis rawat inap, dimana dalam proses setiap data yang ditambahkan akan otomatis tersimpan di data sub rekam medis rawat inap.

Petugas Rekam Medis melakukan pengolahan data retensi yang datanya diambil dari data sub rekam medis rawat inap untuk dipilah menjadi data aktif, inaktif, dan non aktif serta dibuatkan laporan retensi untuk dilaporkan kepada Direktur RS dan Kepala Rekam Medis.

Perancangan basis data bertujuan untuk membentuk tempat penyimpanan data pada media penyimpanan.

ERD adalah suatu model relasi yang menggunakan susunan data yang disimpan dalam sistem secara abstrak. disajikan pada gambar 11. 


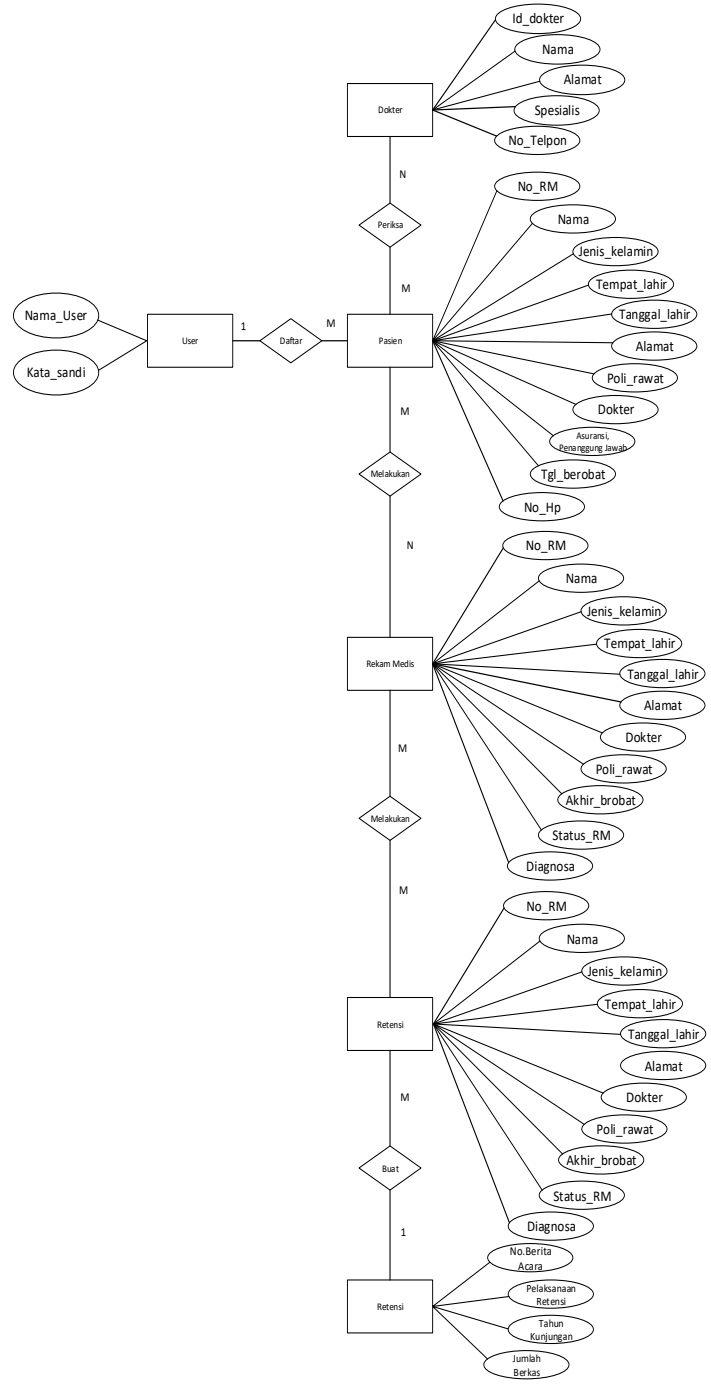

Gambar 11

\section{Entity Relationanship Diagram}

(ERD)

Petugas rekam medis melakukan input data pasien dan dokter terlebih dahulu untuk dapat.

\section{B. Pembahasan}

Berdasarkan hasil observasi, wawancara yang telah dilakukan oleh peneliti, kebutuhan fungsional aplikasi retensi dalam penelitian ini adalah menu data rekam medis, menu user, menu beranda, menu retensi rekam medis, menu unggah berkas, menu pemusnahan rekam medis, menu berkas hilang dan menu laporan. Menu beranda adalah halaman utama pada saat petugas rekam medis atau user dan kepala rekam medis berhasil login. Pada beranda terdapat menu yang bisa diakses diantaranya yaitu menu data master, menu transaksi dan menu laporan. Pada menu data master terdapat 2 submenu yaitu data rekam medis dan data user. Data rekam medis adalah menu untuk mengelola data pasien dan hanya bisa diakses oleh user. Menu data rekam medis mempunyai beberapa fungsi yaitu:

a) User dapat menambahkan, melihat, mengubah dan menghapus data pasien.

b) Adanya fitur import data pasien dalam bentuk Microsoft excel yang dihasilkan oleh sistem informasi pendaftaran rumah sakit.

Menu data user adalah menu untuk mengelola data user yang dapat mengakses aplikasi retensi. Data user hanya bisa diakses oleh kepala rekam medis dan mempunyai beberapa fungsi yaitu fungsi untuk menambahkan, melihat, mengubah dan menghapus data user. User dapat mengakses menu retensi rekam medis. Menu retensi mempunyai beberapa fungsi yaitu:

a) Melihat daftar rekam medis yang sudah masuk waktu retensi.

b) Menu retensi otomatis akan memilah rekam medis berdasarkan tanggal terakhir kunjungan pasien.

c) Rekam medis yang tidak ditemukan saat proses retensi dapat diberi keterangan untuk memudahkan retensi selanjutnya.

d) Mencetak laporan retensi rekam medis.

Menu pemusnahan rekam medis adalah menu untuk mengelola data rekam medis yang siap musnah. Fungsi yang terdapat didalam menu ini yaitu user dapat melihat rekam medis yang sudah masuk waktu pemusnahan dan mencetak laporan pemusnahan rekam medis. User dapat mengakses menu unggah berkas. Adapun fungsi dari menu ini yaitu: 
a) Menambahkan hasil scan berkas rekam medis.

b) Melihat scan berkas rekam medis yang telah ditambahkan.

c) Memberi centang penting untuk berkas yang dianggap penting.

User dapat mengakses menu berkas hilang. Pada menu ini dapat ditampilkan daftar berkas yang tidak ditemukan pada saat proses retensi. Nantinya rekam medis dapat dicari kembali pada saat retensi berikutnya. Kemudian menu laporan yang dapat diakses oleh kepala rekam medis yang digunakan untuk melihat dan mencetak laporan retensi rekam medis dan pemusnahan rekam medis.

Pembuatan aplikasi retensi berdasarkan hasil analisis permasalahan yang ada di Rumah Sakit Jasa Kartini Tasikmalaya diketahui retensi masih menggunakan sistem manual. Petugas harus melihat satu-tanggal terakhir kunjungan pasien yang menyebabkan lamanya proses pencarian berkas. Dengan adanya aplikasi retensi bertujuan untuk memudahkan proses retensi, agar proses pencarian berkas rekam medis menjadi lebih cepat. Aplikasi retensi otomatis akan menampilkan rekam medis yang sudah inaktif. Adanya aplikasi retensi sesuai dengan kebutuhan yang diinginkan oleh petugas rekam medis yaitu aplikasi yang dapat melakukan pemilahan rekam medis.

Berdasarkan penelitian yang dilakukan Retensi adalah pemindahan dokumen rekam medis aktif ke inaktif karena pasien tidak pernah datang kembali dalam waktu sekurang-kurangnya 5 tahun terhitung mulai dari tahun terakhir berobat.

Aplikasi ini membuktikan dapat melakukan proses pemilahan secara otomatis dengan proses yang lebih mudah, sesuai pernyataan diatas proses retensi dilakukan untuk memilah berkas rekam medis yang sudah inaktif. Berikut ini merupakan gambar menu retensi dari aplikasi retensi berkas rekam medis sebagai berikut:

Implementasi Antar Muka :

Tampilan form login disajikan pada gambar 12.

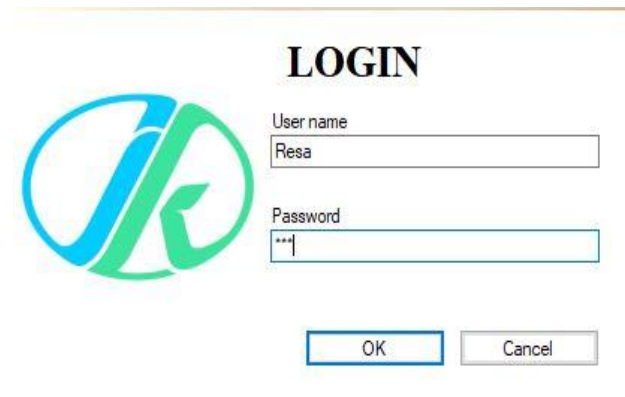

Gambar 12

Layar Login

Pada halaman ini adalah untuk dapat masuk ke halaman utama dan menggunakan fasilitas yang ada di dalamnya.

Tampilan Form Menu Utama disajikan pada gambar 13 .

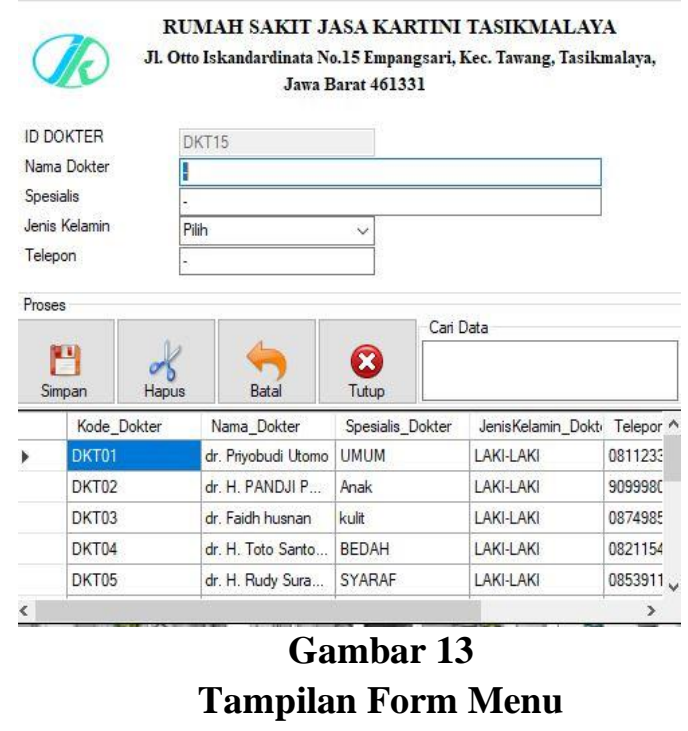

Halaman menu utama berfungsi untuk memilih menu apa yang akan di akses oleh admin. Menu utama menampilkan fiturfitur sistem informasi, seperti: menu user, menu dokter, data pasien, retensi dan laporan. 
Perancangan Sistem Informasi Retensi Rekam Medis Pasien Rawat Inap Menggunakan Visual Studio 2010 di Rumah Sakit Jasa Kartini Tasikmalaya gambar 14.

Tampilan Data User disajikan pada

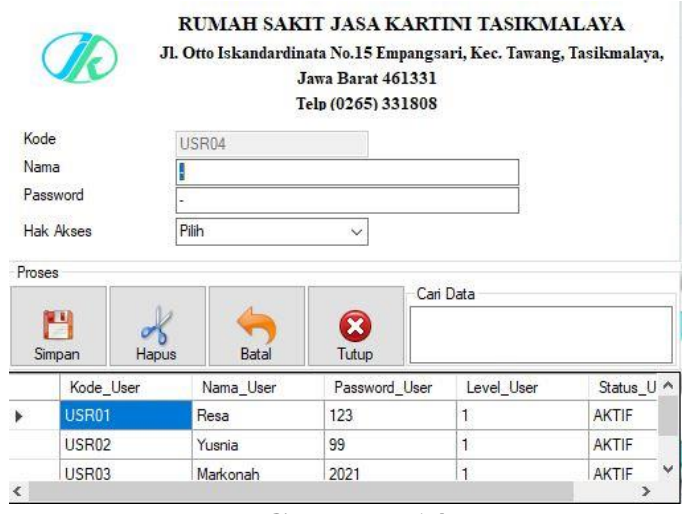

Gambar 14

Tampilan Data User

Data user yaitu untuk menginputkan data petugas yang akan bisa mengakses sistem informasi.

Tampilan Data Dokter disajikan pada gambar 15 .

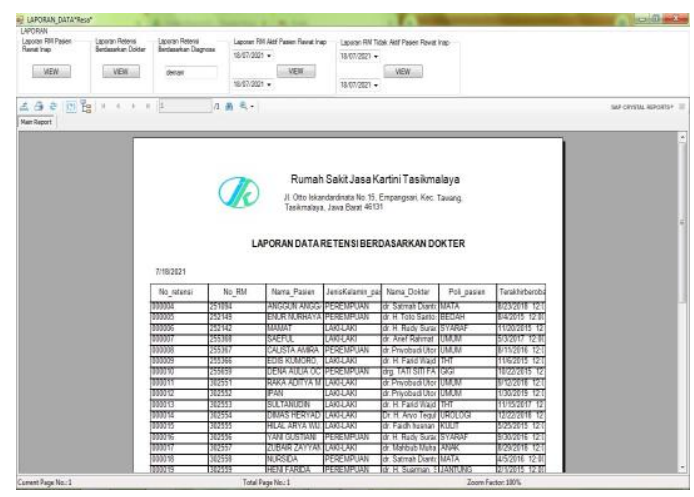

Gambar 15

Tampilan Data Dokter

Tampilan menu dokter terdiri dari fitur tambah dokter berfungsi untuk menambahkan data dokter dan fitur list dokter untuk melihat data dokter yang sudah tersimpan.

Tampilan Form Data Dokter disajikan pada gambar 16.

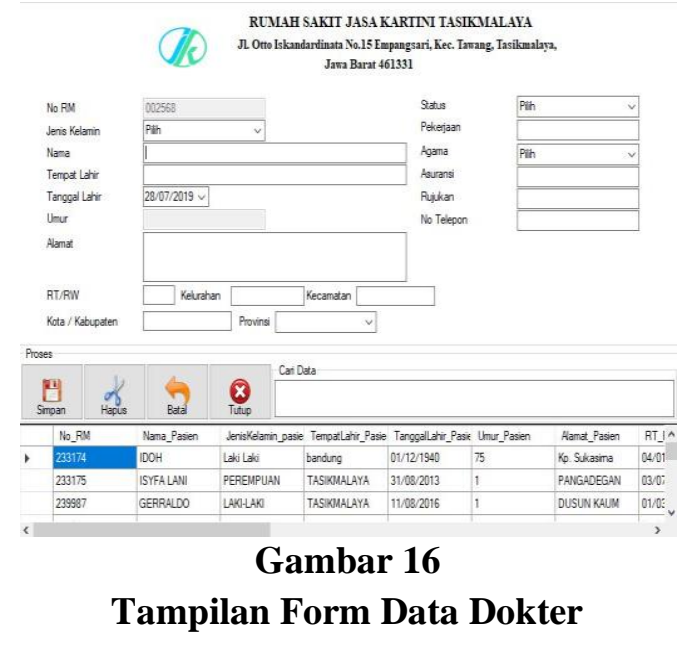

Tampilan Form data dokter terdiri dari fitur tambah dokter berfungsi untuk tambah pasien berfungsi untuk menambah pasien baru dan fitur list pasien untuk melihat data pasien yang pernah berobat.

Tampilan Data Retensi disajikan pada gambar 17.

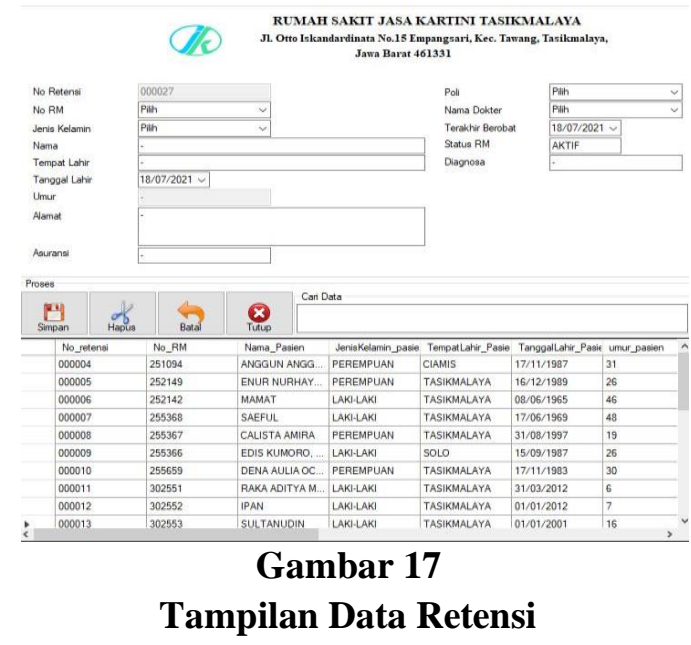

Tampilan menu retensi berfungsi untuk pemilahan rekam medis secara otomatis akan menampilkan rekam medis yang sudah inaktif.

Tampilan Menu Laporan data pasien disajikan pada gambar 18. 


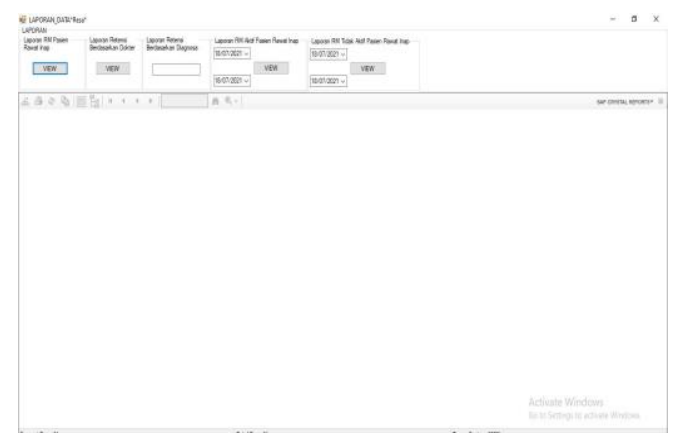

\section{Gambar 18}

Tampilan Menu Laporan Data Pasien

Tampilan Menu ini berisikan tentang laporan dokumen dijadikan image dan dapat digunakan kembali jika ketika dibutuhkan kembali.

Tampilan data RM pasien rawat inap disajikan pada gambar 19.

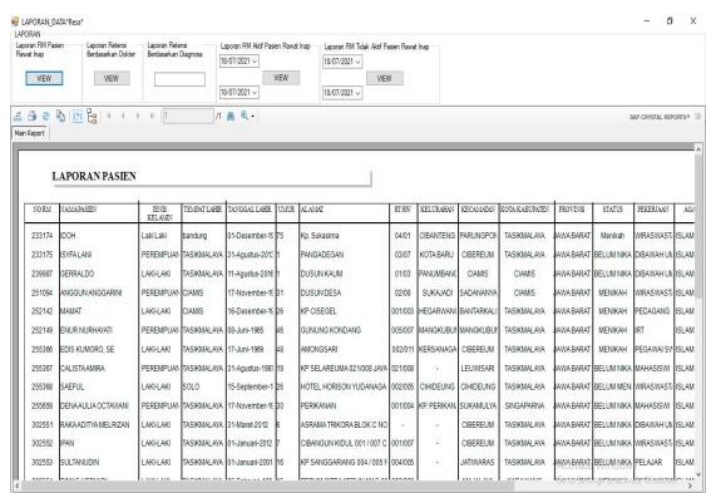

Gambar 19

Laporan data RM pasien rawat inap

Tampilan Laporan Data Retensi berdasarkan Dokter disajikan pada gambar 20.

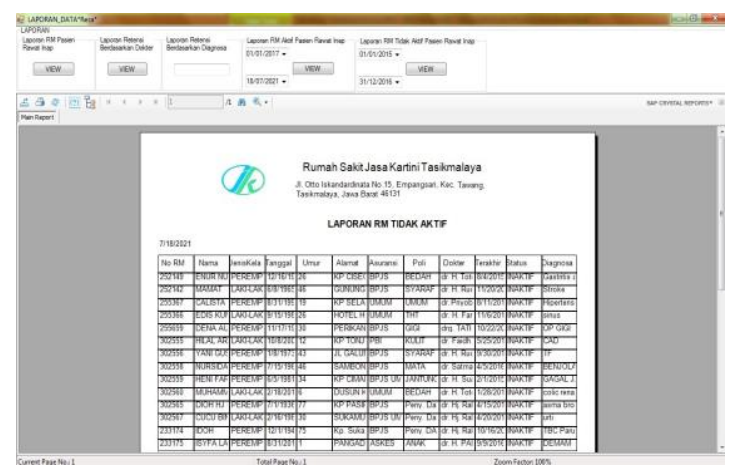

Gambar 20

Tampilan Laporan retensi berdasarkan Dokter

Tampilan Laporan Data Retensi berdasarkan Diagnosa disajikan pada gambar 21.

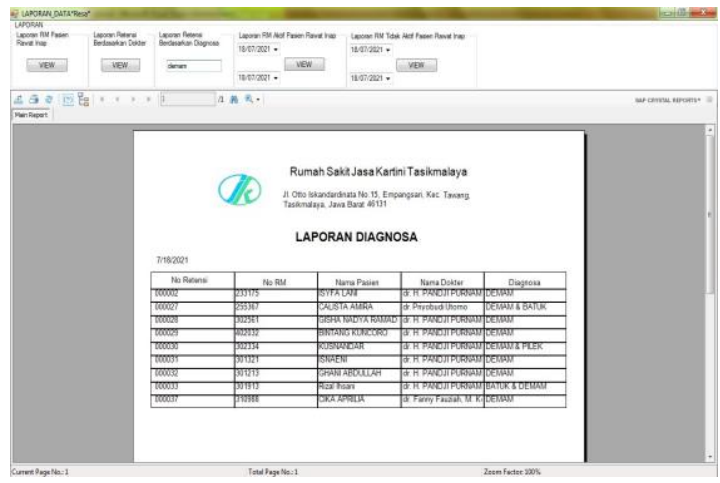

Gambar 21

Tampilan Laporan Retensi Berdasarkan Diagnosa

Tampilan Laporan Retensi RM Aktif pasien rawat inap disajikan pada gambar 21.

Pengujian sistem informasi ini menggunakan metode pengujian black box. Pengujian blackbox menguji spesifikasi suatu fungsi atau modul apakah berjalan sesuai dengan yang diharapkan atau tidak. Cara pengujiannya hanya dilakukan dengan menjalankan dan mengeksekusi unit atau modul, metode ini digunakan untuk mengetahui apakah perangkat lunak ini dapat berfungsi sesuai dengan hasil yang di harapkan. 


\section{Kesimpulan}

Berdasarkan hasil penelitian yang telah dilakukan, maka penulis dapat membuat kesimpulan secara keseluruhan dari sistem informasi retensi rekam medis pasien rawat inap di Rumah Sakit Jasa Kartini Tasikmalaya ialah Sistem retensi rekam medis pasien rawat inap di Rumah Sakit Jasa Kartini Tasikmalaya belum sepenuhnya komputerisasi. Karena pada saat kegiatan pemilahan berkas antara aktif, inaktif dan nonaktif masih dilakukan dengan cara manual. Maka sistem informasi retensi rekam medis pasien rawat inap masih memerlukan pengembangan lebih lanjut. Permasalahan yang terjadi pada kegiatan retensi rekam medis pasien rawat inap di Rumah Sakit Jasa Kartini Tasikmalaya adalah Sistem retensi rekam medis pasien rawat inap belum sepenuhnya komputerisasi, rekam medis yang telah diretensi disimpan sembarangan di ruang penyimpanan, sehingga rekam medis tidak tertata baik sehingga tidak berurutan sesuai nomor rekam medisnya sehingga membuat pekerjaan semakin memerlukan waktu yang lama, kurangnya rak penyimpanan yang berakibat rekam medis tidak tersimpan secara efisien sehingga beberapa rekam medis ada yang disimpan diluar penyimpanan. Beberapa upaya yang telah dilakukan oleh rumah sakit untuk memecahkan masalah-masalah yang telah dijelaskan sebelumnya ialah pihak rumah sakit telah melakukan upaya dengan membuat sistem informasi retensi rekam medis namun masih digabungkan antara pasien rawat inap dan rawat jalan, berkas retensi yang telah diretensi tidak tertata baik di ruang penyimpanan dan nomor rekam medis tidak berurutan sehingga membuat pekerjaan akan lebih lama, Pihak rumah sakit harus membuat jadwal rutin kegiatan retensi rekam medis pasien rawat inap yaitu setiap setahun sekali agar tercapainya efisiensi dan efektifitas ruang penyimpanan rekam medis pasien rawat inap, Perancangan sistem informasi retensi rekam medis pasien rawat inap memerlukan pengembangan dan perlunya ruangan khusus untuk penyimpanan retensi rekam medis.

Hasil dari pengembangan sistem informasi dalam bentuk program aplikasi retensi rekam medis bisa membantu menemukan solusi dalam menangani permasalahan yang terjadi, sehingga pengolahan data retensi ini lebih efektif dan efisien.

\section{BIBLIOGRAFI}

Ade Supriyadi, W. (2018). Tinjauan Ketetapan Diagnosis Utama Penyebab Dasar Kematian Berdasarkan Icd-10... Journal Perekam Medis Dan Informasi Kesehatan, 1(1), 1-6. Google Scholar

Basabih, M. (2018). Perlukah Keselamatan Pasien Menjadi Indikator Kinerja Rs Blu? Jurnal Administrasi Rumah Sakit Indonesia, 3(2). Google Scholar

Hatta, M. (2011). Pengaruh Tipe Jarak Tanam Terhadap Anakan, Komponen Hasil, Dan Hasil Dua Varietas Padi Pada Metode Sri. Jurnal Floratek, 6(2), 104113. Google Scholar

Khariza, H. A. (2015). Program Jaminan Kesehatan Nasional (Studi Deskriptif Tentang Faktor-Faktor Yang Dapat Mempengaruhi Keberhasilan Implementasi Program Jaminan Kesehatan Nasional Di Rumah Sakit Jiwa Menur Surabaya). Universitas Airlangga. Google Scholar

Kusuma, F. A., \& Sugiarsi, S. (2010). Analisis Kelengkapan Data Penunjang Tahun 2010 Dalam Penentuan Kode Diagnosis Utama Hypertensioncomplicating Pregnancy Pasienrawat Inap Di Rsud Wonogiri. Rekam Medis, 4(1). Google Scholar

Pratiwi, Y. E. (2013). Ketepatan Penentuan Kode Penyebab Dasar Kematian Pasien Di Rumah Sakit Umum Daerah Kota 
Resa Yusnia, Sali Setiatin, Widya Nadiroh, Candra Mecca Sufyana

Salatiga Triwulan Iv Tahun 2010. Jurnal Manajemen Informasi Kesehatan Indonesia (Jmiki), 1(1). Google Scholar

Pressman, J. G., Richardson, S. D., Speth, T. F., Miltner, R. J., Narotsky, M. G., Hunter E Sidney, I. I. I., Rice, G. E., Teuschler, L. K., Mcdonald, A., \& Parvez, S. (2010). Concentration, Chlorination, And Chemical Analysis Of Drinking Water For Disinfection Byproduct Mixtures Health Effects Research: Us Epa's Four Lab Study. Environmental Science \& Technology, 44(19), 7184-7192. Google Scholar

Rikomah, S. E. (2017). Farmasi Rumah Sakit. Deepublish. Google Scholar

Sugiyono, P. (2011). Metodologi Penelitian Kuantitatif Kualitatif Dan R\&D. Alpabeta, Bandung. Google Scholar
Syafriani, D. (2018). Karya Tulis Ilmiah Literature Review Ketepatan Kode Diagnosis Hipertensi Berdasarkan Icd 10 Pada Berkas Rekam Medis Pasien. Google Scholar

Taryanto, A., \& Handayani, L. N. (2019). Pengembangan Sistem Informasi Retensi Rekam Medis Di Rumah Sakit Dustira Cimahi. Jurnal E-Komtek (Elektro-Komputer-Teknik), 3(2), 62-70. Google Scholar

Widiyanto, W. W. (2018). Analisa Metodologi Pengembangan Sistem Dengan Perbandingan Model Perangkat Lunak Sistem Informasi Kepegawaian Menggunakan Waterfall Development Model, Model Prototype, Dan Model Rapid Application Development (Rad). Jurnal Informa: Jurnal Penelitian Dan Pengabdian Masyarakat, 4(1), 34-40. Google Scholar

\section{Copyright holder:}

Resa Yusnia, Sali Setiatin, Widya Nadiroh, Candra Mecca Sufyana (2021)

First publication right:

Jurnal Health Sains

This article is licensed under:

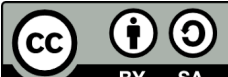

